\title{
Hydrocarbon fluxes above a Scots pine forest canopy: measurements and modeling
}

\author{
J. Rinne ${ }^{1}$, R. Taipale ${ }^{1}$, T. Markkanen ${ }^{1,2}$, T. M. Ruuskanen ${ }^{1}$, H. Hellén ${ }^{3}$, M. K. Kajos ${ }^{1}$, T. Vesala ${ }^{1}$, and M. Kulmala ${ }^{1}$ \\ ${ }^{1}$ Department of Physical Sciences, PL 68, 00014 University of Helsinki, Finland \\ ${ }^{2}$ Department of Micrometeorology, University of Bayreuth, 95440 Bayreuth, Germany \\ ${ }^{3}$ Finnish Meteorological Institute, PL 503, 00101 Helsinki, Finland
}

Received: 9 February 2007 - Published in Atmos. Chem. Phys. Discuss.: 21 February 2007

Revised: 23 May 2007 - Accepted: 30 May 2007 - Published: 27 June 2007

\begin{abstract}
We measured the fluxes of several hydrocarbon species above a Scots pine (Pinus sylvestris) stand using disjunct eddy covariance technique with proton transfer reaction - mass spectrometry. The measurements were conducted during four days in July at SMEAR II research station in Hyytiälä, Finland. Compounds which showed significant emission fluxes were methanol, acetaldehyde, acetone, and monoterpenes. A stochastic Lagrangian transport model with simple chemical degradation was applied to assess the sensitivity of the above canopy fluxes to chemistry. According to the model, the chemical degradation had a minor effect on the fluxes measured in this study but may have a major effect on the vertical flux profiles of more reactive compounds, such as sesquiterpenes. The monoterpene fluxes derived using M81 and M137 had a systematic difference with the latter one being higher. These fluxes followed the traditional exponential temperature dependent emission algorithm but were considerably higher than the fluxes measured before at the same site. The normalized monoterpene emission potentials at $30^{\circ} \mathrm{C}$, obtained using the temperature dependence coefficient of $0.09^{\circ} \mathrm{C}^{-1}$, were $2.0 \mu \mathrm{g} \mathrm{g}_{d w}^{-1} \mathrm{~h}^{-1}$ and $2.5 \mu \mathrm{g} \mathrm{g}_{d w}^{-1} \mathrm{~h}^{-1}$, for fluxes derived using M81 and M137.
\end{abstract}

\section{Introduction}

Reactive hydrocarbons, or volatile organic compounds (VOCs), take part in many chemical processes occurring in the atmospheric boundary layer. Together with nitrogen oxides they are involved in ozone production and destruction processes (Chameides et al., 1992; Fehsenfeld et al., 1992), thus affecting regional ozone pollution. These compounds are also involved in the formation and growth of atmospheric aerosol particles (Kulmala et al., 2004; Tunved et al., 2006)

Correspondence to: J. Rinne

(janne.rinne@helsinki.fi) which affect the transfer of solar radiation in the atmosphere and act as cloud condensation nuclei. In addition VOCs may have an effect on the optical properties of aerosol particles (Nozière and Esteve, 2005). Guenther (2002), Kesselmeier et al. (2002) and Bortoluzzi et al. (2006) have also discussed the role of the biogenic hydrocarbon emissions in the carbon balances of various ecosystems.

Globally, Guenther et al. (1995) have estimated vegetation to emit about seven times more hydrocarbons into the atmosphere than human activity. Also, on a regional scale, in areas with low population density, such as Finland, Simpson et al. (1999) and Lindfors et al. (2000) have estimated that hydrocarbon emissions from vegetation exceed the anthropogenic emissions. About half of the emitted hydrocarbons is comprised of terpenoids, mostly isoprene and monoterpenes (Guenther et al., 1995). The majority of the research on VOC emissions has focused on the isoprene and monoterpene emissions, while non-terpenoid hydrocarbons, making up the other half of the emissions, have received considerably less attention. As a result, emission estimates of these compounds remain highly uncertain.

Recently, both analytical skills and flux measurement methodologies have developed to allow us to measure the emissions of both terpenoid and non-terpenoid hydrocarbons at the canopy scale more directly than in the past. The development and commercialization of the proton transfer reaction-mass spectrometry (PTR-MS) has allowed on-line concentration measurements of hydrocarbons with a reasonably short response time (Lindinger et al., 1998) and the application of the disjunct eddy covariance technique (Rinne et al., 2001; Karl et al., 2002) has enabled us to conduct simultaneous flux measurements of several hydrocarbon species.

As many VOCs have a relatively short lifetime in the atmospheric boundary layer, the above canopy fluxes do not necessarily fully reflect the surface emission. The emitted compounds may for instance react and be transformed to other compounds before they are transported to the measurement

Published by Copernicus Publications on behalf of the European Geosciences Union. 
point. The ratio of the above canopy vertical mixing time $\left(\tau_{\text {mix }}=z / u_{*}\right.$ ) to the chemical lifetime of a compound, called the Damköhler number, $D a=\tau_{\text {mix }} / \tau_{\text {chem }}$, is often used to assess the importance of the chemical degradation on the measured fluxes. However, for tall canopies the below canopy sources, chemistry and transport are not well characterized by this approach. In order to assess the possible impact of the chemical degradation on the fluxes, we used a stochastic Lagrangian transport model with simplified chemical degradation similar to that used by Strong et al. (2004).

Experiments conducted on various plant species and ecosystems have indicated large emissions of such nonterpenoid hydrocarbons as methanol and acetone (Janson et al., 1999; Janson and de Serves, 2001; Warneke et al., 2002; Spirig et al., 2005). However, very little experimental data exist on the emissions of non-terpenoid VOCs from most ecosystems. In Finland, boreal coniferous forests cover about $60 \%$ of the land area and the dominant tree species are Scots pine (Pinus sylvestris L.) and Norway spruce (Picea abies Karst.) (FFRI, 2005). Until now, the non-terpenoid emissions from these ecosystems have been measured only at the branch scale (Janson et al., 1999; Janson and de Serves, 2001). Our aim is to determine the magnitude of the emissions of different non-terpenoid, as well as terpenoid, hydrocarbon species at the canopy scale from a boreal pine forest ecosystem using the disjunct eddy covariance technique combined with proton transfer reaction - mass spectrometry.

\section{Methods}

\subsection{Flux measurements}

We applied the disjunct eddy covariance (DEC) technique to measure the fluxes of VOCs from the Scots pine forest ecosystem. In the disjunct eddy covariance method the flux is calculated as a covariance of the vertical wind speed and trace gas concentration

$F=\left\langle w^{\prime} c^{\prime}\right\rangle=\frac{1}{N} \sum_{i=1}^{N} w_{i}^{\prime} c_{i}^{\prime}$,

where $w^{\prime}=w-\langle w\rangle$ is the momentary deviation of the vertical wind velocity $w$ from its average value, and $c^{\prime}=c-\langle c\rangle$ is that of the trace gas concentration. The brackets denote averages over the measurement period, typically 30-60 min. Each vertical wind speed and trace gas concentration value must be measured with a fast time response instrument in order to take into account the high frequency contribution to the flux. Typically instruments with response times shorter than one second are used in eddy covariance flux measurements.

In contrast to the traditional continuously sampling eddy covariance technique, in the disjunct eddy covariance technique the vertical wind speed and trace gas concentration values used for the flux calculation have a relatively long time interval between them. The sub-sampling of the continuous time series does increase the random uncertainty of the measured flux value, but does not lead to systematic errors as long as the averaging period is much longer than the integral time-scale of $w^{\prime} c^{\prime}$ (Lenschow et al., 1994). The variant of the DEC technique we are utilizing, first used by Karl et al. (2002), takes the advantage of the features of the PTR-MS analyzer. The PTR-MS method is based on detecting charged molecules that are selected according to their mass. The response time of the fast response PTR-MS is well below one second making it capable of eddy covariance measurements with continuous sampling. However, PTR-MS is not able to measure more than one mass at a time. In the DEC method which we utilize, concentrations of different masses are thus measured cyclically, each mass for less than a second. The whole cycle, with the successive mass measurements, can last anything from a few seconds up to half a minute. A disjunct time series of each mass measured with fast response time is thus formed, which is then correlated with the vertical wind speed.

The different variants of DEC technique have been intercompared experimentally with the traditional continuously sampling eddy covariance method by Ammann et al. (2006) and Rinne et al. (2007) ${ }^{1}$. Both observed good correlation with the fluxes measured by the DEC and conventional continuously sampling eddy covariance methods. In the intercomparison experiment by Rinne et al. (2007) $)^{1}$ grab samplers similar to those used by Rinne et al. (2001), Warneke et al. (2002) and Grabmer et al. (2004) were utilized. On the other hand, Ammann et al. (2006) utilized the variant of DEC which we are using here and which has previously been used by Karl et al. (2002, 2003, 2004, 2005) and Spirig et al. (2005).

Our measurement system consisted of an acoustic anemometer (Gill Instruments Ltd., Solent HS1199), $8 \mathrm{~mm}$ i.d., $32 \mathrm{~m}$ long sample line with $15 \mathrm{~L} \mathrm{~min}^{-1}$ flow rate, and a proton transfer reaction - mass spectrometer (PTR-MS, Ionicon Analytik GmbH). The acoustic anemometer and inlet of the sample line were at the height of $22 \mathrm{~m}$ above the ground. The three-dimensional wind data was measured continuously at a rate of $10 \mathrm{~Hz}$ and recorded on a separate computer. The concentrations of selected VOCs were measured with the PTR-MS by pulling a side flow of $0.1 \mathrm{~L} \mathrm{~min}^{-1}$ from the main sample line via $1 \mathrm{~m}$ long tubing with inner diameter of $1.6 \mathrm{~mm}$ (Fig. 1). The measurement cycle lasted about $5.9 \mathrm{~s}$ and consisted of measurements of primary ion and water cluster signals and seven masses associated with VOCs (Table 1). The compounds contributing to the masses measured by PTR-MS have been discussed by de Gouw and Warneke (2007).

Due to the residence time of the air sample in the sample tubing, there is a lag-time between the moment when the

\footnotetext{
${ }^{1}$ Rinne, J., Douffet, T., Prigent Y., and Durand, P.: Field comparison of disjunct and conventional eddy covariance techniques for trace gas flux measurements, Environ. Pollut., submitted, 2007.
} 
Table 1. PTR-MS measurement cycle used in the flux measurements, together with the compounds contributing to the measured masses and integration, or dwell, times. The total cycle length was $5.9 \mathrm{~s}$.

\begin{tabular}{llll}
\hline $\begin{array}{l}\text { Protonated } \\
\text { mass (amu) }\end{array}$ & Contributing compound & $\begin{array}{l}\text { Formula of the } \\
\text { contributing compound }\end{array}$ & $\begin{array}{l}\text { Integration } \\
\text { (dwell) time }\end{array}$ \\
\hline 21 & water isotope & $\mathrm{H}_{2}^{18} \mathrm{O}$ & 0.2 \\
25 & (control mass) & & 0.2 \\
32 & oxygen & $\mathrm{O}_{2}$ & 0.2 \\
33 & methanol & $\mathrm{CH}_{3} \mathrm{OH}$ & 0.5 \\
37 & water cluster & $\mathrm{H}_{2} \mathrm{OH}_{2} \mathrm{O}$ & 0.2 \\
39 & water cluster & $\mathrm{H}_{2} \mathrm{OH}_{2}^{18} \mathrm{O}$ & 0.2 \\
45 & acetaldehyde & $\mathrm{C}_{2} \mathrm{H}_{4} \mathrm{O}$ & 0.5 \\
55 & water cluster & $3\left(\mathrm{H}_{2} \mathrm{O}\right)$ & 0.2 \\
57 & water cluster & $2\left(\mathrm{H}_{2} \mathrm{O}\right) \mathrm{H}_{2}^{18} \mathrm{O}$ & 0.2 \\
59 & acetone & $\mathrm{C}_{3} \mathrm{H}_{6} \mathrm{O}$ & 0.5 \\
81 & fragment of monoterpenes & & 0.5 \\
99 & hexenal & $\mathrm{C}_{6} \mathrm{H}_{10} \mathrm{O}$ & 0.5 \\
101 & hexanal & $\mathrm{C}_{6} \mathrm{H}_{12} \mathrm{O}$ & 0.5 \\
137 & monoterpenes & $\mathrm{C}_{10} \mathrm{H}_{16}$ & 0.5 \\
\hline
\end{tabular}

concentration signal is drawn into the sample line and the time when it is measured by the analyzer. This causes a time lag between the vertical wind velocity and VOC concentration time series. Additional source of uncertainty in the timing of these time series is caused by the use of two separate computers. We determined the time lag between the vertical wind speed time series and the concentration time series by finding the maximum in the covariance function. This is the standard method for determination of the time lag used in the $\mathrm{CO}_{2}$ flux measurement networks (Moncrieff et al., 1997; Aubinet et al., 2000).

The uncertainty of the flux value is determined using the standard deviation of the covariance function far from its maximum value (Spirig et al., 2005). If we assume this standard deviation to be normally distributed we obtain $95 \%$ confidence interval by multiplying the standard deviation $\sigma$ by 1.96 , as $95 \%$ of normally distributed data lies within $\pm 1.96 \sigma$ from the mean value.

\subsection{VOC concentration measurements}

We calculated the VOC concentrations, $c_{i}$, according to

$c_{i}=\alpha_{i}\left[\frac{S_{i}}{\left(\delta_{\mathrm{M} 21 / \mathrm{M} 19}^{-1} S_{\mathrm{M} 21}+S_{\mathrm{M} 37}\right)}-\frac{S_{i, \text { zero }}}{\left(\delta_{\mathrm{M} 21 / \mathrm{M} 19}^{-1} S_{\mathrm{M} 21, \text { zero }}+S_{\mathrm{M} 37, \text { zero }}\right)}\right]$,

where $\alpha_{i}$ is the calibration coefficient, $S_{i}$ is the signal of the mass in cps, $S_{i, \text { zero }}$ is the signal of the mass when hydrocarbon free air is being fed to the analyzer, $S_{\mathrm{M} 21}$ and $S_{\mathrm{M} 37}$ are signals of M21 and M37 during the measurements, respectively, and $S_{\mathrm{M} 21 \text {, zero }}$ and $S_{\mathrm{M} 37 \text {, zero }}$ are those during the measurement of zero air. $\delta_{\mathrm{M} 21 / \mathrm{M} 19}=0.002$ is the ratio of $\mathrm{H}_{3}^{18} \mathrm{O}^{+}$ to $\mathrm{H}_{3}^{16} \mathrm{O}^{+}$. We obtained the calibration coefficients by di- rect calibration with gas standard and inverting the Eq. (2) to yield $\alpha_{i}$.

The PTR-MS was calibrated weekly using a VOC standard mixture (Apel-Riemer Environmental Inc.) that contained all compounds associated with the measured masses except for hexenal. The concentration of each VOC in the standard was in the range of $1 \mathrm{ppm}$ per compound. The standard gas was diluted to the range of $50 \mathrm{ppb}$ using VOC-free air that was obtained from ambient air with a zero-air generator (Parker ChromGas, model 1001). The background signal of VOCs was measured every second hour from the zero-air.

\subsection{Measurement site}

The measurement site, SMEAR II station $\left(61^{\circ} 51^{\prime} \mathrm{N}\right.$, $24^{\circ} 17^{\prime} \mathrm{E}, 181 \mathrm{~m}$ a.s.1.) in Hyytiälä, Finland, is located in south boreal sub-zone (Vesala et al., 1998; Kulmala et al., 2001; Hari and Kulmala, 2005). Vegetation at the site is dominated by $40 \mathrm{yr}$ old Scots pine (Pinus sylvestris) trees. The canopy height is approximately $15 \mathrm{~m}$. The ground vegetation consists of lingonberry (Vaccinium vitis-idaea), blueberry (Vaccinium myrtillus), and mosses (Pleurozium scheberi; Dicranum polysetum). The dry needle biomass density of Scots pines, obtained by methods described by Ilvesniemi and Liu (2001), was $540 \mathrm{~g} \mathrm{~m}^{-2}$ (2005 data, H. Ilvesniemi ${ }^{2}$, personal communication). The total biomass of ground vegetation at the site was $100 \mathrm{~g} \mathrm{~m}^{-2}$ (Launiainen et al., 2005). Previously, Rinne et al. (2000) and Spanke et al. (2001) have conducted canopy scale VOC emission measurements at the site using gradient techniques. Leaf and branch scale measurements

\footnotetext{
${ }^{2}$ H. Ilvesniemi, Finnish Forest Research Institute, Vantaa, Finland
} 


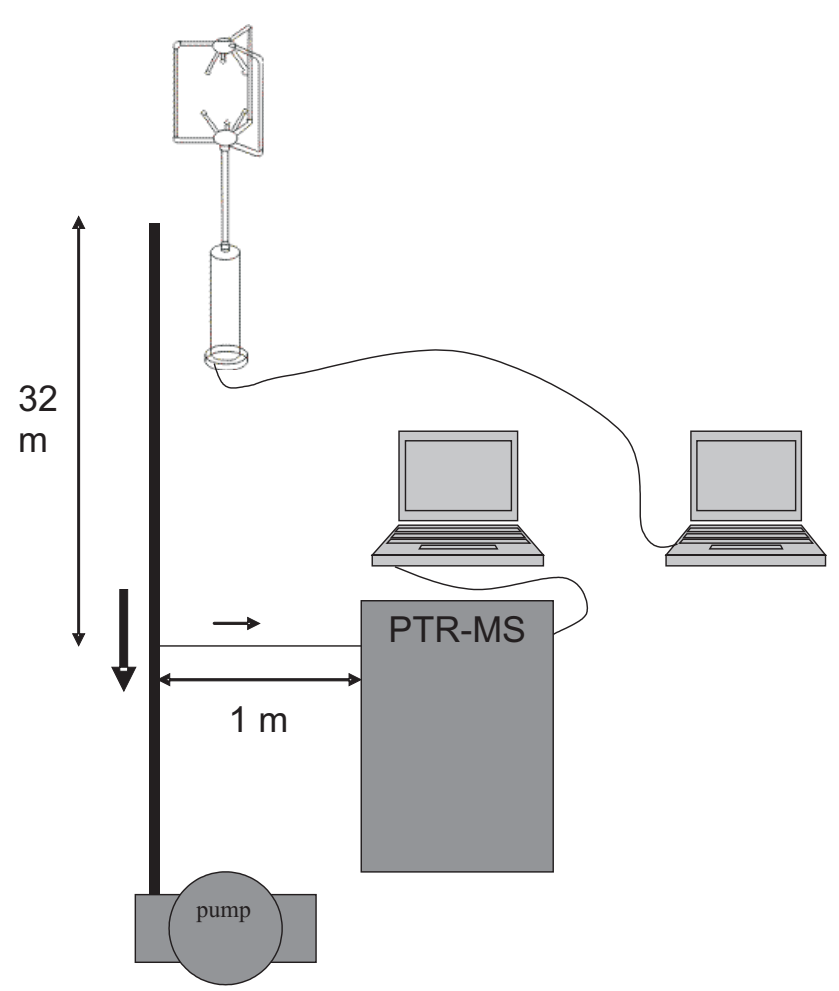

Fig. 1. Schematic of the measurement system. The black lines indicate Teflon tubing with flow direction indicated by arrows. The inner diameter of the long tubing was $8 \mathrm{~mm}$ and the flow in it $15 \mathrm{~L} \mathrm{~min}^{-1}$. The side flow of $0.1 \mathrm{~L} \mathrm{~min}^{-1}$ was taken to the PTRMS via tubing with $1.6 \mathrm{~mm}$ inner diameter.

of the VOC emissions from vegetation at the site have been conducted by Janson and de Serves (2001), Ruuskanen et al. (2005), Tarvainen et al. (2005), Hakola et al. (2006), and Hellén et al. (2006). General overview of long term flux measurements of carbon dioxide, water vapor, ozone and aerosol particles at the site is given by Suni et al. (2003).

The measurements described here were conducted 14-17 July 2005. The air temperature, photosynthetical photon flux density (PPFD) and friction velocity $\left(u_{*}\right)$ during the measurement period are shown in Fig. 2.

\subsection{Modeling the effect of chemical degradation}

We used a stochastic Lagrangian transport model with first order chemical decay (SLTC) to study the effect of the chemical degradation on the fluxes. In the stochastic Lagrangian transport models air parcels are released from a certain height and transported by both mean wind and turbulent motions. The mean wind is given as a pre-described wind profile. Thus the horizontal transport by mean wind depends on the height of the air parcel at each time step. The transport by turbulence is described as a stochastic process which depends on the turbulence statistics. This random displacement due to the turbulence occurs in both horizontal and vertical direction
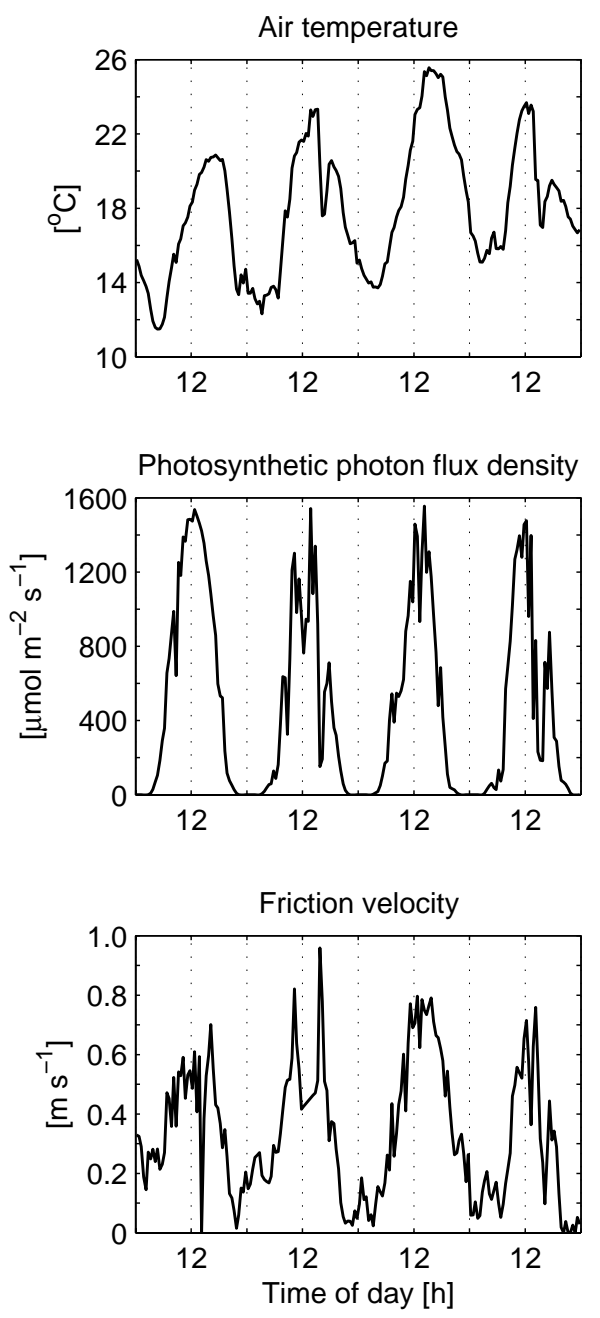

Fig. 2. Air temperature, photosynthetical photon flux density and friction velocity during flux measurements.

at each time step. The transport model without chemistry is described in detail by Markkanen et al. (2003).

In the model with chemical degradation each air parcel is released with the same initial concentration of the trace gas, which is then reduced at each time step due to the chemical degradation. The differential equation describing the degradation of the concentration of a reactive hydrocarbon, $[R]$, in the air parcel can be written as

$$
\begin{aligned}
\frac{\partial[R]}{\partial t}= & -k_{\mathrm{OH}}[\mathrm{OH}][R]-k_{\mathrm{O}_{3}}\left[\mathrm{O}_{3}\right][R] \\
& -k_{\mathrm{NO}_{3}}\left[\mathrm{NO}_{3}\right][R]-k_{\text {photolysis }}[R],
\end{aligned}
$$

where $k_{i}$ are rate coefficients and square brackets denote concentrations of the trace gas, $R$, and oxidants $(\mathrm{OH}$ : hydroxyl radical, $\mathrm{O}_{3}$ : ozone, and $\mathrm{NO}_{3}$ : nitrate radical). Depending on the time of the day different terms in the Eq. (3) can have different importance. For example during night the $\mathrm{OH}$ reaction and photolysis are negligible as there is very little $\mathrm{OH}$ and no 


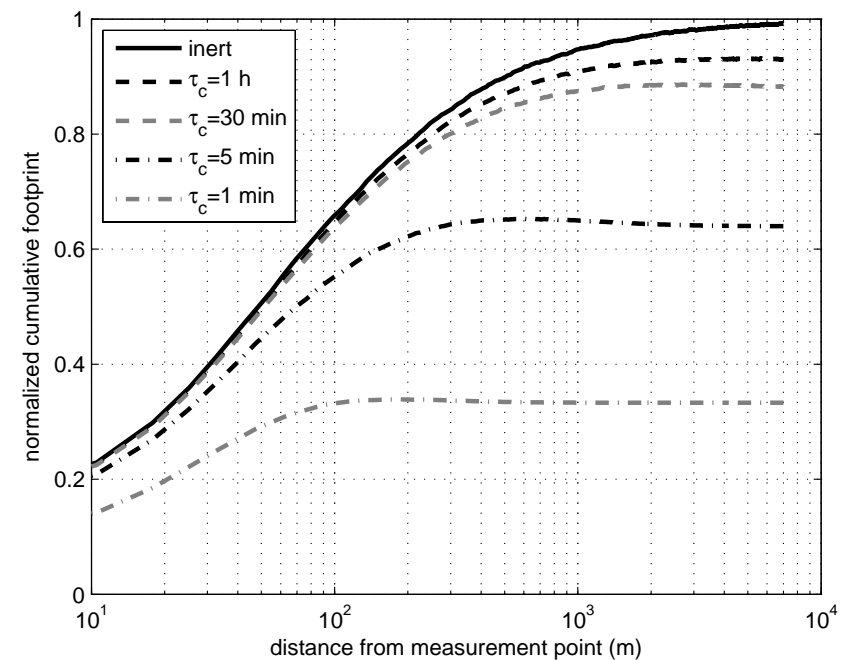

Fig. 3. Effect of chemical degradation on cumulative footprints at the height of $22 \mathrm{~m}$ as calculated by SLTC model for compounds with different chemical lifetimes. The source height was $11.2 \mathrm{~m}$.

solar short wave radiation available. On the opposite, during the daytime the $\mathrm{NO}_{3}$ reaction is negligible. In the Eq. (3) only sink terms are taken into account. However, many compounds, such as methanol and acetone, are also generated in the atmosphere by chemical reactions. In principle these chemical sources can also be taken into account in this kind of model.

Our aim was to obtain information on the sensitivity of the measured fluxes on the chemical degradation of measured hydrocarbons. The change of the VOC concentration was described by a simple first-order differential equation

$\tau_{c} \frac{\partial[R]}{\partial t}+[R]=0$

where the time constant is

$\tau_{c}=\left(k_{\mathrm{OH}}[\mathrm{OH}]+k_{\mathrm{O}_{3}}\left[\mathrm{O}_{3}\right]+k_{\mathrm{NO}_{3}}\left[\mathrm{NO}_{3}\right]+k_{\text {photolysis }}\right)^{-1}$.

If the time constant is time independent, Eq. (4) leads to exponential behavior of the tracer concentration in the air parcel

$[R]=[R]_{0} \exp \left(-t / \tau_{c}\right)$,

where $[R]_{0}$ is the initial concentration. This type of equation was used by Strong et al. (2004).

To study the sensitivity of the measured fluxes on the chemical degradation we used Eq. (6) to calculate the concentration change of the trace gas in the air parcel at each time step during its transport. The concentration was set to unity in the beginning of each trajectory. When the parcel passes the measurement level vertically, the passing is recorded together with the concentration at that moment. Summing up all the passes, weighted with respective concentrations, gives the footprint function for the reactive trace gas. The hydrostatic stability was set to neutral and friction
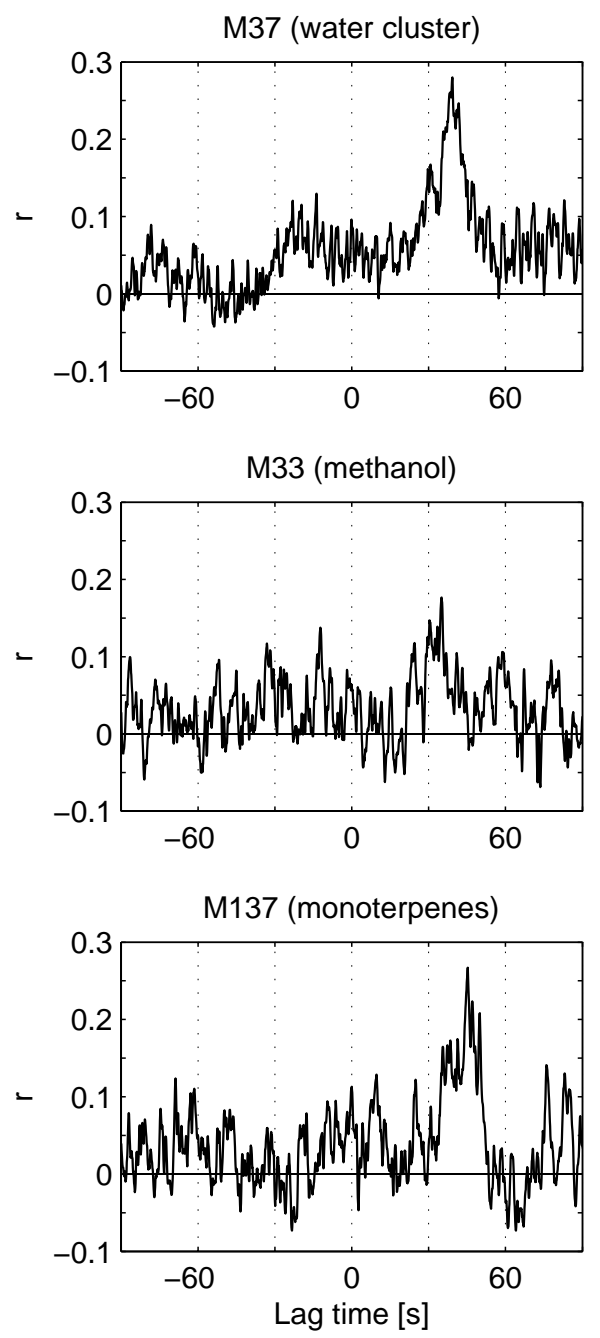

Fig. 4. Correlation functions between vertical wind speed and signals of M37, M33 and M137.

velocity to $0.5 \mathrm{~m} \mathrm{~s}^{-1}$. We used three different oxidant profile types. In the first one the vertical oxidant profiles are taken to be constant. In the second one the oxidant concentration below the canopy is one fourth of that above the canopy, and in the third one the below canopy oxidant concentration is four times of that above the canopy.

Even though the transport model we used is commonly used to calculate flux footprints we were not interested in the footprint itself. The asymptotic behavior of the flux footprint, however, can be used to estimate the effect of the chemical degradation on the fluxes. While the cumulative footprint function of an inert trace gas approaches unity as the distance from the measurement point increases, the cumulative footprint of a reactive hydrocarbon does not reach this value (Fig. 3). The difference between the asymptotic value of the cumulative footprint of the reactive trace gas and that of the inert gas thus shows the effect of the chemical degradation. 

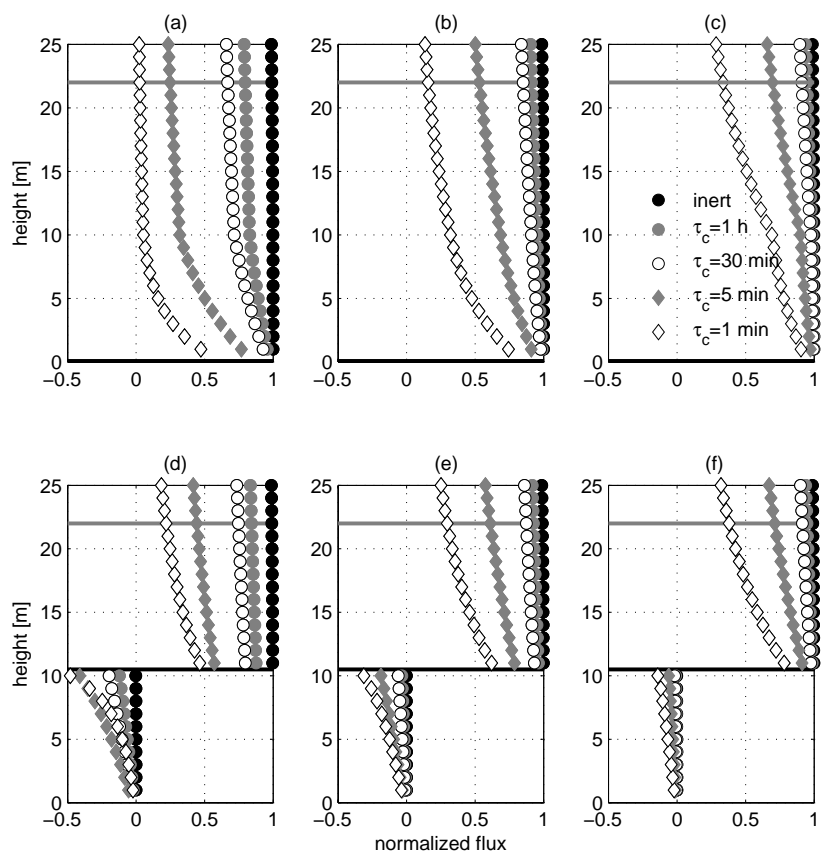

Fig. 5. The normalized vertical flux profiles of trace gases with different chemical lifetimes derived using the SLTC model with sources in the ground (upper row) and sources in the canopy (lower row). Panels (b) and (e): constant oxidant profile. Panels (a) and (d): trace gas lifetime below canopy one fourth of that above canopy. Panels (c) and (f): trace gas lifetime below canopy four times that above canopy. Black horizontal line represents the source height and grey line measurement height used. Lifetimes given in the figure refer to lifetimes above canopy.

The rate constants of some of the compounds measured, and the above canopy chemical lifetimes they yield, are shown in the Tables 2 and 3. The daytime concentration of $\mathrm{OH}$ was taken to be $0.25 \mathrm{ppt}$. This was obtained by the model of Boy et al. (2005). Nighttime concentration of $\mathrm{NO}_{3}$ was taken to be $2.5 \mathrm{ppt}$ (Hakola et al., 2003). During the measurement period ozone concentrations above the canopy varied between 25 and $50 \mathrm{ppb}$, with little systematic difference between daytime and nighttime concentrations. Therefore we used a value of $40 \mathrm{ppb}$ in the calculations. The photolysis rates were calculated as described by Hellén et al. (2004).

\section{Results and discussion}

Of seven masses measured, five showed a more or less clear positive peak in the covariance function indicating upward fluxes. Masses with the clear flux signals were M33 (methanol), M45 (acetaldehyde), M59 (acetone) M81 (monoterpene fragment) and M137 (monoterpenes). Examples of correlation functions of M37 (water cluster), M33 and M137 are given in Fig. 4.

\subsection{Effect of chemistry on fluxes}

Figure 5 shows the asymptotic values of cumulative footprints at different heights for three oxidant profile types and two source heights. These express the vertical profiles of fluxes, normalized by dividing with the primary emission. Two cases, one with sources in the canopy at $11 \mathrm{~m}$, and the other with sources at the surface, are shown. The fraction of the surface emission which reached the flux measurement height clearly depends on the chemical lifetime and the height of the measurement. Also the height of the emission has an effect, as the chemistry has a larger effect on the fluxes of hydrocarbons emitted at the forest floor. Interestingly, the compounds with short chemical lifetimes emitted from the canopy showed negative fluxes below canopy. This was due to the chemical degradation causing flux divergence also below the canopy.

The effect of the chemical degradation was small for the hydrocarbons with longer chemical lifetimes and larger for more short lived compounds. The below canopy chemistry has an effect on the above canopy fluxes of the reactive compounds, even when the emission source is in the canopy. This can be seen well by comparing panels (d) and (e) of the Fig. 5. For example the flux of a compound with chemical lifetime of $30 \mathrm{~min}$ is reduced considerably more in the case where the below canopy lifetime is one fourth of the above canopy value (panel d), than in the case with constant oxidant profile (panel e). Thus we would need information on the oxidant profiles within and below the canopy for more detailed analysis.

In the cases with constant oxidant profile, or the profile where the lifetime below the canopy is four times that above the canopy, the effect of the chemical degradation was small for the hydrocarbons with chemical lifetimes of $30 \mathrm{~min}$ or more. These cases might represent the daytime situation in Hyytiälä with relatively open canopy and low emission of reactive nitrogen from the soil (Pihlatie et al., 2003). For a compound with chemical lifetime of about $5 \mathrm{~min}$ the effect of the chemical degradation is already significant. However, even for hydrocarbons with this short chemical lifetime, a large part of the surface emission reaches the measurement height.

The four compounds with clear emission fluxes during the daytime have daytime lifetimes between half an hour and several days (Table 3). The results of the SLTC model showed that the effect of the chemical degradation had a minor effect on the daytime fluxes of compounds with lifetimes in this range. Thus we can take these above-canopy fluxes to be a good approximation of the surface emission. We can also estimate the magnitude of the sesquiterpene flux at our measurement height by assuming the sesquiterpene emission from the forest to be about $20 \%$ of the monoterpene emissions (Hakola et al., 2006). The fraction of the emission of a compound emitted from the canopy, with lifetime in the range of one minute such as most sesquiterpenes, reaching 
Table 2. Reaction coefficients of selected VOCs with hydroxyl radical $(\mathrm{OH})$, ozone $\left(\mathrm{O}_{3}\right)$ and nitrate radical $\left(\mathrm{NO}_{3}\right)$, and midday photolysis rates in mid-July, calculated as described by Hellén et al. (2004).

\begin{tabular}{lllll}
\hline & $\begin{array}{l}\mathrm{k}(\mathrm{OH}), \\
\mathrm{cm}^{3} \text { molecule }\end{array}$ & $\begin{array}{l}\mathrm{k}\left(\mathrm{O}_{3}\right) \\
\mathrm{cm}^{3} \text { molecule } \mathrm{s}^{-1} \mathrm{~s}^{-1}\end{array}$ & $\mathrm{k}\left(\mathrm{NO}_{3}\right), \mathrm{cm}^{3} \mathrm{molecule}^{-1} \mathrm{~s}^{-1}$ & $\mathrm{k}(\mathrm{photolysis}) \mathrm{s}^{-1}$ \\
\hline methanol & $9.44 \times 10^{-13},(1)$ & - & - & - \\
acetone & $2.19 \times 10^{-13},(1)$ & - & $3.00 \times 10^{-17}$ & $5.03 \times 10^{-7}$ \\
acetaldehyde & $1.58 \times 10^{-11},(1)$ & $5.99 \times 10^{-21},(2)$ & $2.72 \times 10^{-15}$ & $3.39 \times 10^{-6}$ \\
isoprene & $10.1 \times 10^{-11},(1)$ & $1.28 \times 10^{-17},(1)$ & $6.78 \times 10^{-13}(1)$ & - \\
$\alpha-$ pinene & $5.37 \times 10^{-11},(1)$ & $8.66 \times 10^{-17},(1)$ & $6.16 \times 10^{-12}(1)$ & - \\
$\Delta^{3}$-carene & $8.8 \times 10^{-11},(1)$ & $3.70 \times 10^{-17}(1)$ & $9.1 \times 10^{-12}(1)$ & - \\
$\beta-$ caryophyllene & $2.00 \times 10^{-10},(3)$ & $1.16 \times 10^{-14},(3)$ & $1.90 \times 10^{-11},(3)$ & - \\
\hline
\end{tabular}

(1) Atkinson (1994)

(2) Atkinson et al. (1981)

(3) Shu and Atkinson (1995)

Table 3. Atmospheric lifetimes of methanol, acetone, acetaldehyde, $\alpha$-pinene, $\Delta^{3}$-carene and $\beta$-caryophyllene. $\mathrm{OH}$ concentration, $0.25 \mathrm{ppt}$, is estimated by the model described by Boy et al. (2005). $\mathrm{NO}_{3}$ concentration, $2.5 \mathrm{ppt}$, is taken from Hakola et al. (2003). The $\mathrm{O}_{3}$ concentration, $40 \mathrm{ppb}$, was typical for the measurement period.

\begin{tabular}{lllllll}
\hline & $\mathrm{OH}$ & $\mathrm{O}_{3}$ & $\mathrm{NO}_{3}$ & Photolysis & $\begin{array}{l}\text { Day: } \\
\mathrm{OH}+\mathrm{O}_{3}+\text { photol- } \\
\text { ysis }\end{array}$ & $\begin{array}{l}\mathrm{Night}_{3}+\mathrm{O}_{3} \\
\mathrm{NO}\end{array}$ \\
& & & & & $2.0 \mathrm{~d}$ & - \\
\hline methanol & $2.0 \mathrm{~d}$ & - & - & - & $8.7 \mathrm{~d}$ & $17 \mathrm{a}$ \\
acetone & $8.7 \mathrm{~d}$ & - & $17 \mathrm{a}$ & $23 \mathrm{~d}$ & $68 \mathrm{~d}$ \\
acetaldehyde & $2.9 \mathrm{~h}$ & $5.4 \mathrm{a}$ & $70 \mathrm{~d}$ & $3.4 \mathrm{~d}$ & $2.9 \mathrm{~h}$ & $5.2 \mathrm{~h}$ \\
isoprene & $27 \mathrm{~min}$ & $22 \mathrm{~h}$ & $6.7 \mathrm{~h}$ & - & $27 \mathrm{~min}$ & $36 \mathrm{~min}$ \\
$\alpha$-pinene & $51 \mathrm{~min}$ & $3.3 \mathrm{~h}$ & $45 \mathrm{~min}$ & - & $41 \mathrm{~min}$ & $28 \mathrm{~min}$ \\
$\Delta^{3}$-carene & $31 \mathrm{~min}$ & $7.7 \mathrm{~h}$ & $30 \mathrm{~min}$ & - & $29 \mathrm{~min}$ & $1.3 \mathrm{~min}$ \\
$\beta$-caryophyllene & $14 \mathrm{~min}$ & $1.5 \mathrm{~min}$ & $14 \mathrm{~min}$ & - & $1.3 \mathrm{~min}$ & \\
\hline
\end{tabular}

the measurement height of $22 \mathrm{~m}$, is around $30-40 \%$. This would lead to fluxes of sesquiterpenes to be below $10 \%$ of the monoterpene fluxes. Taking into account the fragmentation of sesquiterpenes in the PTR-MS instrument, the difficulties in measuring these highly reactive and sticky compounds through relatively long tubing, and typical instrument noise, these fluxes are well below detection limit.

\subsection{VOC fluxes}

The highest fluxes were those of monoterpenes (Fig. 6). These fluxes, averaging $400-500 \mu \mathrm{g} \mathrm{m}^{-2} \mathrm{~h}^{-1}$, are considerably higher than the monoterpene emissions of around $300 \mu \mathrm{g} \mathrm{m}^{-2} \mathrm{~h}^{-1}$ and $200 \mu \mathrm{g} \mathrm{m}^{-2} \mathrm{~h}^{-1}$ from the same site reported by Rinne et al. (2000) and Spanke et al. (2001), respectively. There was a systematic difference between the monoterpene fluxes calculated using M81 and M137 with the latter being somewhat higher. This difference may be due to the different fragmentation patterns of different monoterpenes. We calibrated the PTR-MS using $\alpha$-pinene standard, which is the most abundant monoterpene at the site (Hakola et al., 2003). Also the ecosystem scale monoterpene emissions from the site have been reported to be dominated by $\alpha$-pinene (Rinne et al., 2000; Spanke et al., 2001). However, branch level measurements have revealed that the emissions from many Scots pine trees were dominated by $\Delta^{3}$-carene (Janson, 1993; Hakola et al., 2006).

The emissions of methanol and acetone were in the same range of magnitude with each other while the acetaldehyde fluxes were the smallest. The fluxes of all these four hydrocarbons show a diurnal cycle with higher fluxes during the day and smaller at night. The uncertainties of the fluxes, defined as $95 \%$ confidence interval, were relatively large.

The fluxes of non-terpenoid compounds are a significant part of the total VOC emission from the forest, comprising nearly half of the measured total VOC emissions on a mass basis (Table 4). This is roughly the same as the proportion of the emissions of other (than isoprene and monoterpene) VOCs globally or in the national level as estimated by Guenther et al. (1995) and Lindfors et al. (2000). Previous 

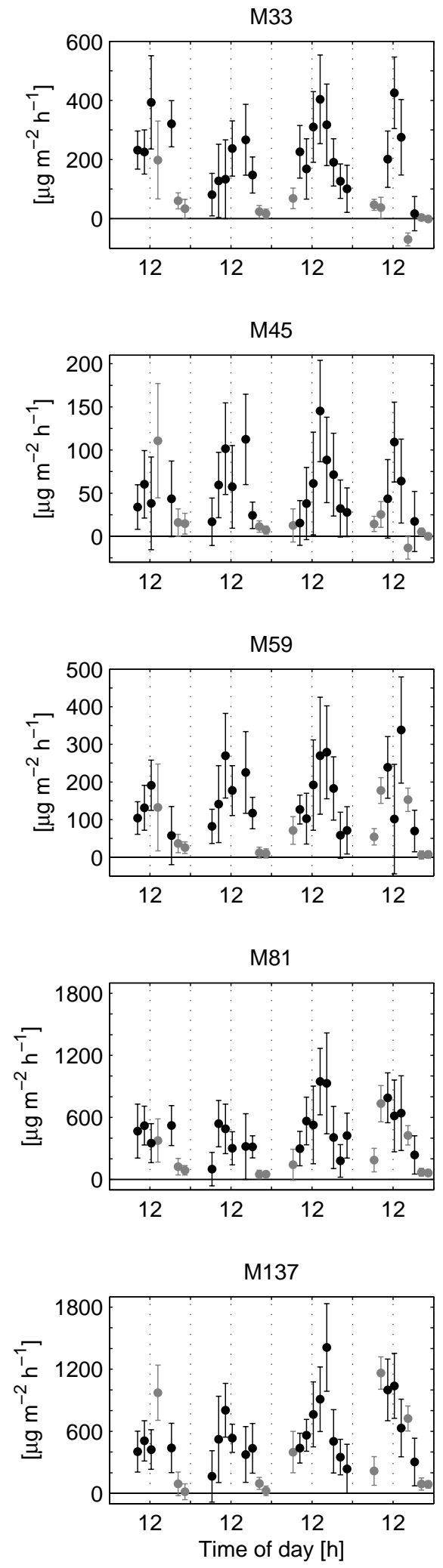

Fig. 6. Measured fluxes of methanol (M33), acetaldehyde (M45), acetone (M59), and monoterpenes derived using M81 (M81) and M137 (M137) (14-17 July 2005). The gray dots indicate the measurement during which the friction velocity was below $0.25 \mathrm{~m} \mathrm{~s}^{-1}$.
Table 4. Average daily ecosystem scale VOC emissions from the Scots pine forest during the measurement period. The monoterpene emission is calculated as an average of the fluxes derived using M81 and M137.

\begin{tabular}{lllll}
\hline & $\mathrm{mg} \mathrm{m}^{-2} \mathrm{~d}^{-1}$ & $\%$ & $\mu \mathrm{mol} \mathrm{m}^{-2} \mathrm{~d}^{-1}$ & $\%$ \\
\hline methanol & 3.9 & 21 & 120 & 44 \\
acetaldehyde & 1.1 & 6 & 24 & 9 \\
acetone & 3.0 & 16 & 52 & 19 \\
monoterpenes & 11 & 57 & 78 & 28 \\
\hline
\end{tabular}

studies conducted by enclosure technique with adsorbent and denuder sampling and gas chromatographic analysis have shown Scots pines to emit monoterpenes, acetone and acetaldehyde (Janson, 1993; Janson et al., 1999; Janson and de Serves, 2001). No methanol emissions from Scots pine were reported as their detection has not been possible due to limitations of measurement methods.

Canopy scale emissions of methanol have previously been reported from coniferous forests such as mixed lodgepole pine, subalpine fir, and Engelman spruce forest (Baker et al., 2001; Karl et al., 2002), ponderosa pine plantation (Schade and Goldstein, 2001), and loblolly pine plantation (Karl et al., 2005). Using only canopy scale flux measurements it is not possible to determine if the methanol was emitted by the canopy or by sub-canopy vegetation. However, Karl et al. (2005) measured significant emissions of methanol from loblolly pine needles. Also ponderosa pine forest floor has been reported to emit methanol, acetone and acetaldehyde (Schade and Goldstein, 2001). Compared to the canopy scale methanol emissions by coniferous forests reported by Baker et al. (2001) and Schade and Goldstein (2001), our measurements showed a relatively low emission (Table 5). The emissions reported by Karl et al. (2005) are in the same range with the measurements reported here.

In comparison to canopy emissions we measured, the monoterpene emissions from the forest floor in summer at Hyytiälä site reported by Hellén et al. (2006) were negligible. Also those measured from a mixed Scots pine - Norway spruce forest floor by Janson et al. (1999) were small compared to the canopy emissions. Thus we may conclude that the monoterpene fluxes we measured originate mainly from the canopy emissions.

The leaf level acetone emissions, measured by Janson et al. (1999) and Janson and de Serves (2001), have a wide range into which the canopy scale emissions presented here fall into, when multiplied by the needle biomass density of the Hyytiälä site (Table 5). No acetaldehyde or acetone emissions from boreal forest floor were reported by Janson et al. (1999). Therefore it seems that the emissions of these carbonyls originate mainly from the canopy.

However, the carbonyls are also produced in the chemical reactions of e.g. mono- and sesquiterpenes. Therefore the 
Table 5. Typical daytime canopy scale fluxes of non-terpenoid VOCs from coniferous forests reported in literature.

\begin{tabular}{|c|c|c|c|c|c|}
\hline & Method & Vegetation & $\begin{array}{l}\text { Methanol } \\
\mathrm{mg} \mathrm{m}^{-2} \mathrm{~h}^{-1}\end{array}$ & $\begin{array}{l}\text { Acetaldehyde } \\
\mathrm{mg} \mathrm{m}^{-2} \mathrm{~h}^{-1}\end{array}$ & $\begin{array}{l}\text { Acetone } \\
\mathrm{mg} \mathrm{m}^{-2} \mathrm{~h}^{-1}\end{array}$ \\
\hline Janson et al. (1999) & Chamber* & Pinus sylvestris & n.a. & n.a. & $0.06-0.2^{+}$ \\
\hline Baker et al. (2001) & REA & $\begin{array}{l}\text { Pinus contorta, Abies lasio- } \\
\text { carpa, Picea engelmannii }\end{array}$ & 3 & n.a. & 4 \\
\hline Janson and de Serves (2001) & Chamber* & Pinus sylvestris & n.a. & n.a. & $0.02-1$ \\
\hline Schade and Goldstein (2001) & REA & Pinus ponderosa & 3 & 0.3 & 0.3 \\
\hline Karl et al. (2002) & $\mathrm{DEC}$ & $\begin{array}{l}\text { Pinus contorta, Abies lasio- } \\
\text { carpa, Picea engelmannii }\end{array}$ & 1 & 0.4 & 0.8 \\
\hline Karl et al. (2005) & DEC & Pinus taeda & 0.3 & deposition & 0.4 \\
\hline This study, Average $10-17 \mathrm{~h}$ & $\mathrm{DEC}$ & Pinus sylvestris & 0.25 & 0.086 & 0.23 \\
\hline
\end{tabular}

* Canopy scale emission obtained by multiplying with the needle biomass density of $540 \mathrm{~g}_{d w} \mathrm{~m}^{-2}$

+ Based on total carbonyl emission of $3-6 \mathrm{nmol} \mathrm{g}_{d w}^{-1} \mathrm{~h}^{-1}$ of which acetone comprised $79 \pm 13 \%$

chemical reactions may contribute positively to the fluxes of these compounds but this chemical production was not taken into account in our simple model.

\subsection{Emission potentials}

Fluxes of all four compounds, methanol, acetone, acetaldehyde and monoterpenes, had a clear diurnal cycle (Fig. 6), which could be due to diurnal cycles in temperature, solar radiation or some biological factors. Emissions of monoterpenes from evergreen plants having resin ducts, such as Scots pine, have usually been taken to depend only on leaf or needle temperature (Janson, 1993; Komenda and Koppmann, 2002; Tarvainen et al., 2005). The temperature dependence of the monoterpene emission is usually described by the equation

$E=E_{30} \exp \left[\beta\left(T-30^{\circ} \mathrm{C}\right)\right]$,

where $E$ is the emission, $E_{30}$ is the normalized emission potential, and $\beta$ is the temperature dependence coefficient (Guenther et al., 1993). By fitting an exponential curve to the measured monoterpene fluxes we obtained temperature dependence coefficients of $0.095^{\circ} \mathrm{C}^{-1}$ and $0.11^{\circ} \mathrm{C}^{-1}$ for fluxes derived using M81 and M137, respectively. The emission rates standardized to $30^{\circ} \mathrm{C}$, using these temperature dependence factors, were $1.07 \mathrm{mg} \mathrm{m}^{-2} \mathrm{~h}^{-1}$ and $1.55 \mathrm{mg} \mathrm{m}^{-2} \mathrm{~h}^{-1}$ for M81 and M137, respectively (Fig. 7). The data with friction velocity less than $0.25 \mathrm{~m} \mathrm{~s}^{-1}$ were removed from this analysis. This friction velocity limit is a general data quality criterium for fluxes measured at the Hyytiälä site (Markkanen et al., 2001). The temperature dependence is in the range with previous observations (Janson, 1993; Janson and de Serves, 2001; Rinne et al., 1999, 2000; Spanke et al., 2001; Tarvainen et al., 2005; Hakola et al., 2006). By using the temperature dependence coefficient of $0.09^{\circ} \mathrm{C}^{-1}$, commonly used in the emission inventory models, we arrived at the normalized emission potentials at $30^{\circ} \mathrm{C}$ of $1.10 \mathrm{mg} \mathrm{m}^{-2} \mathrm{~h}^{-1}$ and
$1.37 \mathrm{mg} \mathrm{m}^{-2} \mathrm{~h}^{-1}$ for monoterpene fluxes derived from M81 and M137, respectively. Assuming that all the monoterpenes were emitted by the Scots pine needles and using the needle biomass density of $540 \mathrm{~g}_{d w} \mathrm{~m}^{-2}$, we obtained an emission potential of $2.0 \mu \mathrm{gg}_{d w}^{-1} \mathrm{~h}^{-1}$ and $2.5 \mu \mathrm{g} \mathrm{g}_{d w}^{-1} \mathrm{~h}^{-1}$ for monoterpene fluxes derived using M81 and M137, respectively. These are considerably higher than the value of $1.2 \mu \mathrm{gg}_{d w}^{-1} \mathrm{~h}^{-1}$ obtained for the same measurement site by Rinne et al. (2000) using surface layer gradient technique.

There can be several reasons for the differences between normalized emission potentials we obtained and those reported previously. When comparing canopy scale emission measurements to the emissions measured in the branch scale using enclosure technique, one has to be aware that the canopy scale measurements include emissions from sources which are not measured by the branch enclosure technique. For example emissions from ground vegetation and tree trunks can contribute to the canopy scale fluxes. The previous canopy scale measurements above Scots pine forests (Rinne et al., 1999, 2000; Spanke et al., 2001) have been conducted with surface layer gradient technique. As a rather indirect flux measurement technique it may have more sources of systematic uncertainties than direct disjunct eddy covariance technique. Also limonene was not included in the total monoterpene emissions reported by Rinne et al. (1999, 2000). However, limonene contributed only $0.5-1.4 \%$ of the total monoterpene emission from Scots pine (Tarvainen et al., 2005).

As yet, there exists no emission algorithm for nonterpenoid VOC emissions from vegetation. These compounds have been included into some emission inventories using for example the temperature dependent monoterpene emission algorithm (Guenther et al., 1995). However, it seems that the daily cycles of ambient concentrations of the main non-terpenoids emitted in Hyytiälä site, methanol, acetone and acetaldehyde, are governed by different processes 

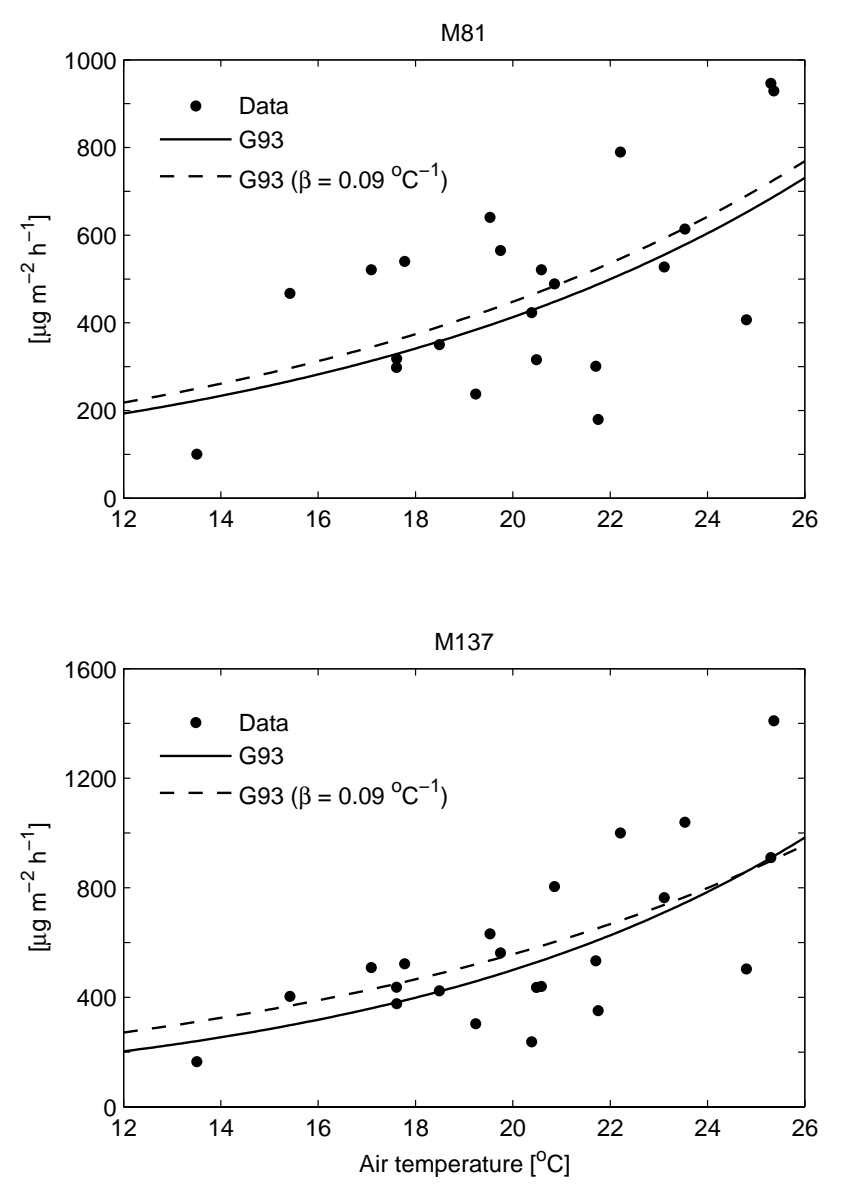

Fig. 7. Monoterpene fluxes derived using M81 (M81) and M137 (M137) as a function of temperature. The solid line indicates the fitting to the temperature dependent emission algorithm while dashed line is that with a fixed temperature dependence coefficient $\beta=0.09^{\circ} \mathrm{C}^{-1}$.

than the daily cycles of monoterpene concentrations (Rinne et al., 2005). As there are differences also in the chemical degradation of these compounds we can not attribute the difference only to the source behavior. Therefore controlled environment leaf or branch level laboratory studies should be conducted in order to reveal the dependencies of emissions of non-terpenoid hydrocarbons on environmental parameters.

\section{Conclusions}

We measured fluxes of several hydrocarbon species above a Scots pine (Pinus sylvestris) forest canopy by the disjunct eddy covariance method utilizing a proton transfer reaction mass spectrometer. We also applied a stochastic Lagrangian transport model with simple chemical degradation to study the sensitivity of the fluxes on the degradation.

Significant fluxes of monoterpenes, methanol, acetone and acetaldehyde were detected. The monoterpene fluxes were considerably higher than those measured previously at the same site but there was a systematic difference between the monoterpene fluxes derived using M81 and M137. The monoterpene fluxes followed the traditional exponentially temperature dependent emission algorithm. Normalized monoterpene emission potentials at $30^{\circ} \mathrm{C}$, obtained using the temperature dependence coefficient of $0.09^{\circ} \mathrm{C}^{-1}$, were $2.0 \mu \mathrm{g} \mathrm{g}_{d w}^{-1} \mathrm{~h}^{-1}$ and $2.5 \mu \mathrm{g} \mathrm{g}_{d w}^{-1} \mathrm{~h}^{-1}$, derived using M81 and M137, respectively These are considerably higher than the values obtained previously. Combined, the emission of acetone, acetaldehyde and methanol was of the same magnitude as the monoterpene emission which is in line with the previous emission inventories.

Of the fluxes presented here, the chemical degradation has the largest effect, about $10 \%$, to the fluxes of monoterpenes. For acetone, acetaldehyde and methanol the effect is even smaller. Thus we can take the fluxes of these compounds to be equivalent to the surface emission. However, if fluxes of more reactive compounds, such as sesquiterpenes, were measured, the chemical degradation should be taken into account in interpreting the results.

Acknowledgements. We thank M. Boy at the University of Helsinki for the hydroxyl radical data and $\mathrm{H}$. Ilvesniemi at the Finnish Forest Research Institute for the needle dry biomass density. We acknowledge Academy of Finland (209216, 109601), Environmental Research Center of the University of Helsinki (URPO) and Kone foundation for financial support.

Edited by: J. Kesselmeier

\section{References}

Ammann, C., Brunner, A., Spirig, C., and Neftel, A.: Technical note: Water vapour concentration and flux measurements with PTR-MS, Atmos. Chem. Phys., 6, 4643-4651, 2006, http://www.atmos-chem-phys.net/6/4643/2006/.

Atkinson, R.: Gas-phase tropospheric chemistry of organic compounds, J. Phys. Chem. Ref. Data. Monogr., 2, 216 p, 1994.

Atkinson, R., Aschmann, S. M., Winer, A. M., and Pitts Jr., J. N.: Rate Constants for the Gas-Phase Reactions of O3 with a Series of Carbonyls at 296 K, Int. J. Chem. Kinet., 13, 1133-1142, 1981.

Aubinet, M., Grelle, A., Ibrom, A., Rannik, Ü., Moncrieff, J., Foken, T., Kowalski, A.S., Martin, P.H., Berbigier, P., Bernhofer, C., Clement, R., Elbers, J., Granier, A., Grunwald, T., Morgenstern, K., Pilegaard, K., Rebmann, C., Snijders, W., Valentini, R., and Vesala, T.: Estimates of the annual net carbon and water exchange of forests: The EUROFLUX methodology, Adv. Ecol. Res., 30, 113-175, 2000.

Baker, B., Guenther, A., Greenberg, J., and Fall, R.: Canopy level fluxes of 2-methyl-3-buten-2-ol, acetone, and methanol by a portable relaxed eddy accumulation system, Environ. Sci. Technol., 35(9), 1701-1708, 2001.

Bortoluzzi, E., Epron, D., Siegenthaler, A., Gilbert, D., and Buttler, A.: Carbon balance of a European mountain bog at contrasting stages of regeneration, New Phytologist, 172, 708-718, 2006. 
Boy, M., Kulmala, M., Ruuskanen, T.M., Pihlatie, M. Reissell, A., Aalto, P.P., Keronen, P., Dal Maso, M., Hellen, H., Hakola, H., Janson, R., Hanke, M., and Arnold, F.: Sulphuric acid closure and contribution to nucleation mode particle growth, Atmos. Chem. Phys., 5, 863-878, 2005,

http://www.atmos-chem-phys.net/5/863/2005/.

Chameides, W. L., Fehsenfeld, F., Rogers, M., Cardelino, C., Martinez, J., Parrish, D., Lonneman, W., Lawson, D. R., Rasmussen, R. A., Zimmerman, P., Greenberg, J., Middleton, P., and Wang, T.: Ozone precursor relationships in the ambient atmosphere, J. Geophys. Res., 97, 6037-6055, 1992.

Fehsenfeld, F., Calvert, J., Fall, R., Goldan, P., Guenther, A., Hewitt, N., Lamb, B., Liu, S., Trainer, M., Westberg, H., and Zimmerman, P.: Emissions of volatile organic compouds from vegetation and the implications for atmospheric chemistry, Global Biogeochem. Cycles, 6, 389-430, 1992.

FFRI: Metsätilastollinen vuosikirja 2005 (Finnish Statistical Yearbook of Forestry 2005), Finnish Forest Research Institute, 424 pp. ISBN 951-40-1985-7, 2005.

de Gouw, J. and Warneke, C.: Measurements of volatile organic compounds in the Earth's atmosphere using proton-transferreaction mass spectrometry, Mass Spectrom. Rev., 26, 223-257, 2007.

Grabmer, W., Graus, M., Lindinger, C., Wisthaler, A., Rappenglück, B., Steinbrecher, R., and Hansel, A.: Disjunct eddy covariance measurements of monoterpene fluxes from a Norway spruce forest using PTR-MS, Int. J. Mass Spectrom., 239, 111$115,2004$.

Guenther, A. B., Zimmerman, P. R., Harley, P. C., Monson, R. K., and Fall, R.: Isoprene and monoterpene emission rate variability: Model evaluation and sensitivity analysis, J. Geophys. Res., 98, 12 609-12 617, 1993.

Guenther, A., Hewitt, C. N., Erickson, D., Fall, R., Geron, C., Graedel, T., Harley, P., Klinger, L., Lerdau, M., McKay W. A., Pierce T., Scholes, B., Steinbrecher, R., Tallamraju, R., Taylor, J., and Zimmerman, P.: A global model of natural volatile organic compound emissions, J. Geophys. Res., 100, 8873-8892, 1995.

Guenther, A.: The contribution of reactive carbon emissions from vegetation to the carbon balance of terrestrial ecosystems, Chemosphere, 49, 837-844, 2002.

Hakola, H., Tarvainen, V., Laurila, T., Hiltunen, V., Hellén, H., and Keronen, P.: Seasonal variation of VOC concentrations above a boreal coniferous forest, Atmos. Environ., 37, 1623-1634, 2003.

Hakola, H., Tarvainen, V., Bäck, J., Ranta, H., Bonn, B., Rinne, J., and Kulmala, M.: Seasonal variation of mono- and sesquiterpene emission rates of Scots pine, Biogeosciences, 3, 93-101, 2006, http://www.biogeosciences.net/3/93/2006/.

Hari, P. and Kulmala, M.: Station for measuring ecosystematmosphere relations (SMEAR II), Bor. Environ. Res., 10, 315322, 2005

Hellén, H., Hakola, H., Reissell, A., and Ruuskanen, T. M.: Carbonyl compounds in coniferous forest air in Hyytiälä, Southern Finland, Atmos. Chem. Phys., 4, 1771-1780, 2004, http://www.atmos-chem-phys.net/4/1771/2004/.

Hellén, H., Hakola, H., Pystynen, K.-H., Rinne J., and Haapanala, S.: $\mathrm{C}_{2}-\mathrm{C}_{10}$ hydrocarbon emissions from a boreal wetland and forest floor, Biogeosciences, 3, 167-174, 2006, http://www.biogeosciences.net/3/167/2006/.
Ilvesniemi, H. and Liu, C.: Biomass distribution in a young Scots pine stand, Boreal Environ. Res., 6, 3-8, 2001.

Janson, R. W.: Monoterpene emission from Scots pine and Norwegian spruce, J. Geophys. Res., 98, 2839-2850, 1993.

Janson, R., de Serves, C., and Romero, R.: Emission of isoprene and carbonyl compounds from a boreal forest and wetland in Sweden, Agric. For. Meteorol., 98, 671-681, 1999.

Janson, R. and de Serves, C.: Acetone and monoterpene emissions from the boreal forest in northern Europe, Atmos. Environ., 35, 4629-4637, 2001.

Karl, T. G., Spirig, C., Rinne, J., Stroud, C., Prevost, P., Greenberg, J., Fall R., and Guenther, A.: Virtual disjunct eddy covariance measurements of organic trace compound fluxes from a subalpine forest using proton transfer reaction mass spectrometry, Atmos. Chem. Phys., 2, 279-291, 2002,

http://www.atmos-chem-phys.net/2/279/2002/.

Karl, T., Guenther, A., Spirig, C., Hansel, A., and Fall, R.: Seasonal variation of biogenic VOC emissions above a mixed hardwood forest in northern Michigan, Geophys. Res. Lett., 30, 2186, doi:10.1029/2003GL018432, 2003.

Karl, T., Potosnak, M., Guenther, A., Clark, D., Walker, J., Herrick, D., and Geron, C.: Exchange processes of volatile organic compounds above a tropical rain forest: Implications for modeling tropospheric chemistry above dense vegetation, J. Geophys. Res., 109, D18306, doi:10.1029/2004JD004738, 2004.

Karl, T., Harley, P., Guenther, A., Rasmussen, R., Baker, B., Jardine, K., and Nemitz, E.: The bi-directional exchange of oxygenated VOCs between a loblolly pine (Pinus taeda) plantation and the atmosphere, Atmos. Chem. Phys., 5, 3015-3031, 2005, http://www.atmos-chem-phys.net/5/3015/2005/.

Kesselmeier, J., Ciccioli, P., Kuhn, U., Stefani, P., Biesenthal, T., Rottenberger, S., Wolf, A., Vitullo, M., Valentini, R., Nobre, A., Kabat, P., and Andreae, M. O.: Volatile organic compound emissions in relation to plant carbon fixation and the terrestrial carbon budget, Global Change Biol., 16, 1126, doi:10.1029/2001GB001813, 2002.

Komenda, M. and Koppmann, R.: Monoterpene emissions from Scots pine (Pinus sylvestris): Field studies of emission rate variabilities, J. Geophys. Res., 107, 4161, doi:10.1029/2001JD000691, 2002.

Kulmala, M., Hämeri, K., Aalto, P. P., Mäkelä, J. M., Pirjola, L., Nilsson, E. D., Buzorius, G., Rannik, Ü., Dal Maso, M., Seidl, W., Hoffman, T., Janson, R., Hansson, H.C., Viisanen, Y., Laaksonen, A., and O'Dowd, C. D.: Overview of the international project on biogenic aerosol formation in the boreal forest (BIOFOR), Tellus, 53B, 324-343, 2001.

Kulmala, M., Suni, T., Lehtinen, K.E.J., Dal Maso, M., Boy, M., Reissell, A., Rannik, Ü., Aalto, P., Keronen, P., Hakola, H., Bäck, J. B., Hoffmann, T., Vesala, T., and Hari, P.: A new feedback mechanism linking forests, aerosols, and climate, Atmos. Chem. Phys., 4, 557-562, 2004, http://www.atmos-chem-phys.net/4/557/2004/.

Launiainen, S., Rinne, J., Pumpanen, J., Kulmala, L., Kolari, P., Keronen, P., Siivola, E., Pohja, T., Hari P., and Vesala, T.: Eddycovariance measurements of $\mathrm{CO} 2$ and sensible and latent heat fluxes during a full year in a boreal pine forest trunk-space, Bor. Environ. Res., 10, 569-588, 2005.

Lenschow, D. H., Mann, J., and Kristensen, L.: How long is long enough when measuring fluxes and other turbulence statistics? 
J. Atmos. Ocean. Technol., 11, 661-673, 1994.

Lindfors, V., Laurila, T., Hakola, H., Steinbrecher, R., and Rinne, J.: Modeling speciated terpenoid emissions from the European boreal forest, Atmos. Environ., 34, 4983-4996, 2000.

Lindinger, W., Hansel, A., and Jordan, A.: Review: On-line monitoring of volatile organic compounds at pptv levels by means of Proton-Transfer-Reaction Mass Spectrometry (PTR-MS), Medical applications, food control and environmental research, Int. J. Mass Spec. Ion Proc., 173, 191-241, 1998.

Markkanen, T., Rannik, U., Keronen, P., Suni, T., and Vesala, T.: Eddy covariance fluxes over a boreal Scots pine forest, Bor. Environ. Res., 6, 65-78, 2001.

Markkanen, T., Rannik, Ü., Marcolla, B., Cescatti, A., and Vesala, T.: Footprints and fetches for fluxes over forest canopies with varying structure and density, Boundary-Layer Meteorol., 106, 437-459, 2003.

Moncrieff, J. B., Massheder, J. M., deBruin, H., Elbers, J., Friborg, T., Heusinkveld, B., Kabat, P., Scott, S., Soegaard, H., and Verhoef, A.: A system to measure surface fluxes of momentum, sensible heat, water vapour and carbon dioxide, J. Hydrol., 189, 589-611, 1997.

Nozière, B. and Esteve, W.: Organic reactions increasing the adsorbtion index of atmospheric sulfuric acid aerosols, Geophys. Res. Lett., 32, L03812, doi:10.1029/2004GL021942, 2005.

Pihlatie, M., Ilvesniemi, H., Simojoki, A., Pumpanen, J., Regina, K., Hari, P., and Vesala, T.: Nitrogen oxide and methane fluxes from boreal pine forest soil, in: Research Unit on Physics, Chemistry and Biology of Atmospheric Composition and Climate Change: Progress Report and Proceedings of Seminar in Hyytiälä 12-14 March 2003, edited by: Kulmala, M. and Korhonen, H., Report Series in Aerosol Science, no 59, Finnish Association for Aerosol Research, 64-67, 2003.

Rinne, J., Hakola, H., and Laurila, T.: Vertical fluxes of monoterpenes above a Scots pine stand in the boreal vegetation zone, Phys. Chem. Earth, 24, 711-716, 1999.

Rinne, J., Hakola, H., Laurila, T., and Rannik, Ü.: Canopy scale monoterpene emissions of Pinus sylvestris dominated forests, Atmos. Environ., 34, 1099-1107, 2000.

Rinne, H. J. I., Guenther, A. B., Warneke, C., de Gouw, J. A., and Luxembourg, S. L.: Disjunct eddy covariance technique for trace gas flux measurements, Geophys. Res. Lett., 28, 3139-3142, 2001.

Rinne, J., Ruuskanen, T. M., Reissell, A., Taipale, R., Hakola, H., and Kulmala, M.: On-line PTR-MS measurements of atmospheric concentrations of volatile organic compounds in a European boreal forest ecosystem, Bor. Environ. Res., 10, 425-436, 2005.

Ruuskanen, T. M., Kolari, P., Bäck, J., Kulmala, M., Rinne, J., Hakola, H., Taipale, R., Raivonen, M., Altimir, N., and Hari, P.: On-line field measurements of monoterpene emissions from Scots pine by proton transfer reaction - mass spectrometry, Bor. Environ. Res., 10, 553-567, 2005.
Schade, G. W. and Goldstein, A. H.: Fluxes of oxygenated volatile organic compounds from a ponderosa pine plantation, J. Geophys. Res., 106, 3111-3123, 2001.

Shu, Y. and Atkinson, R: Atmospheric lifetimes and fates of a series of sesquiterpenes, J. Geophys. Res., 100, 7275-7281, 1995.

Simpson, D., Winiwarter, W., Börjesson, G., Cinderby, S., Ferreiro, A., Guenther, A., Hewitt, N., Janson, R., Khalil, M. A. K., Owen, S., Pierce, T., Puxbaum, H., Shearer, M., Skiba, U., Steinbrecher, R., Tarrasón, L., and Öquist, M. G.: Inventorying emissions from nature in Europe, J. Geophys. Res., 104, 8113-8152, 1999.

Spanke, J., Rannik, Ü., Forkel, R., Nigge, W., and Hoffmann, T.: Emission fluxes and atmospheric degradation of monoterpenes above a boreal forest: field measurements and modeling, Tellus, B53, 406-422, 2001.

Spirig, C., Neftel, A., Ammann, C., Dommen, J., Grabmer, W., Thielmann, A., Schaub, A., Beauchamp, J., Wisthaler, A., and Hansel, A.: Eddy covariance flux measurements of biogenic VOCs during ECHO 2003 using proton transfer reaction mass spectrometry, Atmos. Chem. Phys., 5, 465-481, 2005, http://www.atmos-chem-phys.net/5/465/2005/.

Strong, C., Fuentes, J. D., and Baldocchi, D.: Reactive hydrocarbon footprints during canopy senescence, Agric. For. Meteorol., 127, 159-173, 2004.

Suni, T., Rinne, J., Reissell, A., Altimir, N., Keronen, P., Rannik, Ü. Dal Maso, M., Kulmala, M., and Vesala, T.: Long-term measurements of surface fluxes above a Scots pine forest in Hyytiälä, southern Finland, 1996-2001, Bor. Environ. Res., 8, 287-301, 2003.

Tarvainen, V., Hakola, H., Hellen, H., Bäck, J., Hari, P., and Kulmala, M.: Temperature and light dependence of the VOC emissions of Scots pine, Atmos. Chem. Phys., 5, 989-998, 2005, http://www.atmos-chem-phys.net/5/989/2005/.

Tunved, P., Hansson, H.-C., Kerminen, V.-M., Ström, J., Dal Maso, M., Lihavainen, H., Viisanen, Y., Aalto, P. P., Komppula, M., and Kulmala, M.: High natural aerosol loading over Boreal forests, Science, 312, 261-263, 2006.

Vesala, T., Haataja, J., Aalto, P., Altimir, N., Buzorius, G., Keronen, P., Lahti, T., Markkanen, T., Mäkelä, J.M., Nikinmaa, E., Palmroth, S., Palva, L., Pohja, T., Pumpanen, J., Rannik, Ü., Siivola, E., Ylitalo, H., Hari, P., and Kulmala, M.: Long-term field measurements of atmosphere-surface interactions in boreal forest combining forest ecology, micrometeorology, aerosol physics and atmospheric chemistry, Trends in Heat Mass and Momentum Transfer, 4, 17-35, 1998.

Warneke, C., Luxembourg, S. L., de Gouw, J. A., Rinne, H. J. I., Guenther, A. B., and Fall, R.: Disjunct eddy covariance measurements of oxygenated volatile organic compound fluxes from an alfalfa field before and after cutting, J. Geophys. Res., 107, D8, doi:10.1029/2001JD000594, 2002. 